\title{
Fundamental Study on Emulsion-Fuels (II)
}

\section{-Effects of Hydrophobic Chain Lengths in Normal Alcohols on Water Content and Particle Size in W/O Type Emulsions-}

\author{
Masahiko ABE, Hiroshi Nishino, and Keizo OGINO
}

(Faculty of Science and Technology, Science University of Tokyo)

SYNOPSIS:- The effects of hydrophobic chain lengths in normal alcohols on the particle size and the water content in W/O type emulsions have been investigated.

Adding alcohols to the solution of nonionic surfactants containing shorter alkyl chain and/or longer POE chain resulted in the increasing of water content and the decreasing of particle size of W/O type emulsion. With decreasing alkyl chain in alcohol molecule, the water content and particle size in W/O type emulsions increased. These addition effect of alcohols was considerably recognized in the case of nonionic surfactant in which has a strong hydrophilic group.

This may be due to that adding alcohols to the solution influences on adsorptive state of surfactant at interface between water and oil; molecules of nonionic surfactant per unit emulsion decrease; as a result, the numbers of emulsion increase.

\section{Key Words}

W/O type emulsion, Particle size, Water content, Nonionic surfactant, Interfacial tension, Alcohol 


\section{炭化水素による窒素酸化物の除去}

(キーワード 窒素酸化物, 還元, 炭化水素, 流通反応装置)

-1988. 5. 6 受理一

公害資源研究所 宮 寺 達 雄

\section{1. 緒言}

燃焼炉内の一次燃焼ゾーン後流部に二次燃料を吹き 込んで, 還元雾囲気にして窒素酸化物 $\left(\mathrm{NO}_{\mathrm{x}}\right)$ を除去

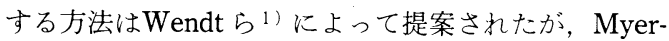
sonの研究 ${ }^{2)}$ 等を経て, 再酸化過程も含めた高橋らの 研究 $\left.{ }^{3 ）} 4\right) に よ り$ 炉内脱硝法として実用の域に達した。 燃料過剩条件下での反応メカニズムに関してMyerso$\mathrm{n}^{2)}$ は, $\mathrm{O}_{2}$ が $\mathrm{CH}, \mathrm{CH}_{2}$ 等の炭化水素ラジカルの生成を 促進し, NOは炭化水素ラジカルと反応してN, HCN に転化すると考えた。還元雾囲気下での $\mathrm{NO}_{\mathrm{x}}$ 転化反応 に関する研究は多いが, 再酸化後の最終的な $\mathrm{NO}_{\mathrm{x}}$ 除去 率がどのような因子に支配されるかを検討した研究は 少ない。再酸化過程の入口ガス組成は $\mathrm{NO}_{\mathrm{x}}$ 転化過程の 反応条件の影響も受けるから, 両過程の反応条件を総 合的に検討する必要がある。これらを詳細に調べるた めに管型流通反応装置を用いて実験を行った。 $\mathrm{NO}_{\mathrm{x}}$ の 還元剂としては直鎖状飽和炭化水素 (メタン, エタン, プロパン， $\mathrm{n}$ ブタン）を用いた。メタン，エタンに ついてはすでに結果の一部を発表したので，ここでは プロパンに関する結果を中心に報告する。

\section{2. 実 験}

電気炉で加熱した断面積 $2.97 \mathrm{~cm}^{2}$ の石英製または磁 製の反応管に炭化水素, $\mathrm{O}_{2}, \mathrm{NO}, \mathrm{N}_{2},\left(\mathrm{CO}_{2}, \mathrm{SO}_{2}, \mathrm{H}_{2}\right.$ O)を予混合した試料ガスを流して反応させた。炭化 水素は, いずれる純度 $99 \%$ 以上のボンベガスをそのま ま使用した。酸素不足の条件下で生成する中間生成物 を完全酸化するために二次酸素の添加，二次加熱を行 つた。一番目の反応管之二番目の反応管の連結部は断 面積 $0.46 \mathrm{~cm}^{2}$ と細くしてあり，加熱された試料はここ を約 0.013 秒で通過する。反応管内の温度分布は反応 管中心軸上に置いた石英製または磁製の内管に熱電対 (JIS R)を挿入して測定した。本実験においては窒素 茨城県つくば市小野川 16-3

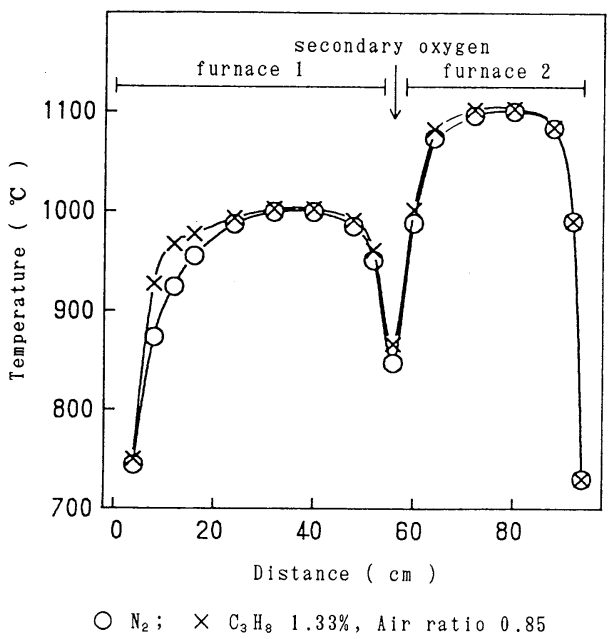

Fig. 1 Temperature distribution in the reactor

のみを流した場合の最高温度を指標に加熱用電気炉の 温度を設定し, 固定した。炭化水素, 酸素等を流して 反応させると温度分布はFig. 1 のよらになる。温度分 布は空気比（入口酸素量／炭化水素の完全酸化に必要 な化学量論酸素量), 炭化水素濃度等によって変化し, 最高温度も窒素のみを流した場合より最大 $3 \sim 4{ }^{\circ} \mathrm{C}$ 高 くなった。以下に示す温度は, 窒素のみを流した場合 の最高温度である。 $1000^{\circ} \mathrm{C}$ における $22^{\circ} \mathrm{C}$ 以内の均熱 部の長さは, 一段めの反応管で $12 \mathrm{~cm}$, 二段めの反応 管で $10 \mathrm{~cm}$ であった。ガスの流量制御には石けん膜流 量計で校正したマスフローコントローラを用いた。そ の他，反応装置に関する詳細は既報 ${ }^{5)}$ のとおりであ る。反応後のガスは必要に応じて冷却，除湿，または 加温して分析装置またはサンプリング装置へ導いた。 $\mathrm{NO}_{\mathrm{x}}$ は化学発光式窒素酸化物分析計, $\mathrm{O}_{2}$ は磁気式酸素 計, $\mathrm{CO}, \mathrm{CO}_{2}, \mathrm{H}_{2}$, 炭化水素, $\mathrm{N}_{2} \mathrm{O}, \mathrm{HCN}$ はガスクロマ トグラフ, $\mathrm{NH}_{3}$ はイオン電極を用いて，それぞれ測定 
した。窒素酸化物の供給源としてはボンベ入りのNO $2 \% / \mathrm{N}_{2}$ を用いたが，ガス混合時に数 $\mathrm{ppm} の \mathrm{NO}_{2}$ が生 成することから, 本研究ではNOと $\mathrm{NO}_{2}$ の両方を測定 して $\mathrm{NO}_{\mathrm{x}}$ と表示した。ただし，著しく低い空気比で反 応させた後のガスは窒素酸化物分析計のコンバータで 干渉を起こす場合もあったので，その場合にはコン バータを通さずにNOのみ測定した。ガスクロマトグ ラフのカラムは, $\mathrm{H}_{2}, \mathrm{CH}_{4}, \mathrm{CO}$ 用にはモレキュラー シーブ13X60-80メッシュ $3 \phi \times 3 \mathrm{~m}, \mathrm{CO}_{2}, \mathrm{C}_{3} \mathrm{H}_{8}, \mathrm{C}_{2} \mathrm{H}_{2}$ 用 にはガスクロ工業製unibeads iS 60-80メッシュ $3 \phi \times 2 \mathrm{~m}, \mathrm{n}-\mathrm{C}_{4} \mathrm{H}_{10}$ 用には同unibeads $2 \mathrm{~S}$ 60-80メッシュ $3 \phi \times 2 \mathrm{~m}, \mathrm{~N}_{2} \mathrm{O}$ 用にはポラパック Q 80-100メッシュ $3 \phi \times 3 \mathrm{~m}, \mathrm{HCN}$ 用には島津製作所製 D23(DEGS 25\%/Shimalite) $60-80$ メッシュ3 $3 \times 3 \mathrm{~m}$ を用いた。キ ヤリヤーガスは, $\mathrm{H}_{2}$ の分析時には $\mathrm{N}_{2}$, その他の場合に はHeを用いた。また検出器は，HCNにはフレーム サーミオニック検出器, その他の成分には, 熱伝導度 型検出器を用いた。HCNの分析はJIS K 0109のガス クロマトグラフ法, $\mathrm{NH}_{3}$ の分析はJIS K 0099の隔膜形 アンモニア電極法に基づいて行った。出ロガス流量は, 出口ガス組成の分析值から計算によって求めた。以下, とくに断わらない限り, $\mathrm{NO}_{\mathrm{x}}$ 初濃度 $1000 \mathrm{ppm}$, ガス流 速 $11.2 \mathrm{~cm} / \mathrm{sec}$ (STP) で実験を行った。

\section{3. 結果および考察}

燃焼過程中の窒素化合物の反応に関するSong ら 7) の分類を参考に, 比較的低温における燃料過剩条件下 でのNOの反応を整理すると以下のようになる。 NO転化反応

$$
\begin{aligned}
& \mathrm{CH}+\mathrm{NO} \rightarrow \mathrm{N}+\mathrm{CHO} \\
& \mathrm{CH}+\mathrm{NO} \rightarrow \mathrm{HCN}+\mathrm{O} \\
& \mathrm{CH}_{2}+\mathrm{NO} \rightarrow \mathrm{N}+\mathrm{CH}_{2} \mathrm{O} \\
& \mathrm{CH}_{2}+\mathrm{NO} \rightarrow \mathrm{HCN}+\mathrm{OH}
\end{aligned}
$$

$\mathrm{HCN}$ 転化反応

$\mathrm{HCN}$ から，CN等を経て $\mathrm{N}, \mathrm{NH}, \mathrm{NH}_{2}$ を生成する一 連の反応

$\mathrm{NO}$ 再生反応

$$
\begin{aligned}
& \mathrm{N}+\mathrm{O}_{2} \rightarrow \mathrm{NO}+\mathrm{O} \\
& \mathrm{N}+\mathrm{OH} \rightarrow \mathrm{NO}+\mathrm{H} \\
& \mathrm{NH}+\mathrm{O} \rightarrow \mathrm{NO}+\mathrm{H} \\
& \mathrm{NH}+\mathrm{OH} \rightarrow \mathrm{NO}+\mathrm{H}_{2}
\end{aligned}
$$

$\mathrm{N}_{2}$ 生成反応

$$
\begin{aligned}
& \mathrm{NH}_{2}+\mathrm{NO} \rightarrow \mathrm{N}_{2}+\mathrm{H}_{2} \mathrm{O} \\
& \mathrm{NH}+\mathrm{NO} \rightarrow \mathrm{N}_{2}+\mathrm{OH} \\
& \mathrm{N}+\mathrm{NO} \rightarrow \mathrm{N}_{2}+\mathrm{O} \\
& \mathrm{NH}+\mathrm{NH} \rightarrow \mathrm{N}_{2}+\mathrm{H}_{2} \\
& \mathrm{NH}+\mathrm{N} \rightarrow \mathrm{N}_{2}+\mathrm{H}
\end{aligned}
$$

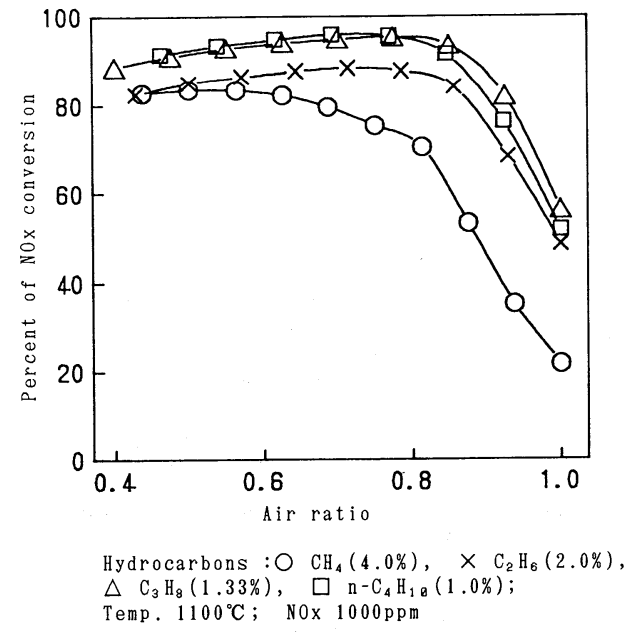

Fig. 2 Nitric oxides conversion in one-stage reaction

本報告では, 実験結果と上記の反応との関係を定性 的に記述するにとどめる。速度定数を用いた，反応機 構に関する定量的取り扱いについては現在検討中であ る。

一番目の反応管でのみ反応させ，二次酸素の添加， 二次加熱を行わない場合を一段反応と呼び，これによ って $\mathrm{NO}_{\mathrm{x}}$ が他の化合物に変化する割合を $\mathrm{NO}_{\mathrm{x}}$ 転化率 (percent of $\mathrm{NO}_{\mathrm{x}}$ conversion) と表示する。二次酸素を 転化せずに二次加熱を行っても，ガス組成は一段反応 の場合とあまり変わらないので一段反応後の温度履歴 は大きな影響を及ぼさないといえる。一段反応におい てNO${ }_{\mathrm{x}}$ 転化率が炭化水素の種類によって変化するよう すをFig. 2に示す。各炭化水素の濃度は, 炭素数で換 算した濃度 (炭化水素分子中の炭素数と容量\%の積) が 等しくなるように設定した。メタン, エタンでは空気 比が高くなると $\mathrm{NO}_{\mathrm{x}}$ 転化率が急激に低下するが，プロ

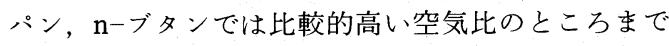
高い $\mathrm{NO}_{\mathrm{x}}$ 転化率が維持される。また, メタンからプロ パンまで炭化水素分子の炭素数が増えるにつれて $\mathrm{NO}_{\mathrm{x}}$ 転化率が高くなる傾向にある。高空気比の領域でNO 転化率が低下するのは, Myerson ${ }^{2)}$ が指摘したように， 適度な $\mathrm{O}_{2}$ は炭化水素ラジカルの生成を促進して $\mathrm{NO}_{\mathrm{x}}$ の 転化反応を進めるが, 過剩な $\mathrm{O}_{2}$ は炭化水素を消費し てしまらためであろら。また，一度生成したHCN等 の中間生成物が高濃度の酸素によって再酸化されるこ とも考元られる。一方, 酸素を添加しなくても $\mathrm{NO}_{\mathrm{x}}$ 転 化反応が認められたことから, 空気比の低、領域では, $\mathrm{NO}_{\mathrm{x}}$ と反応する炭化水素ラジカルが炭化水素の熱分 


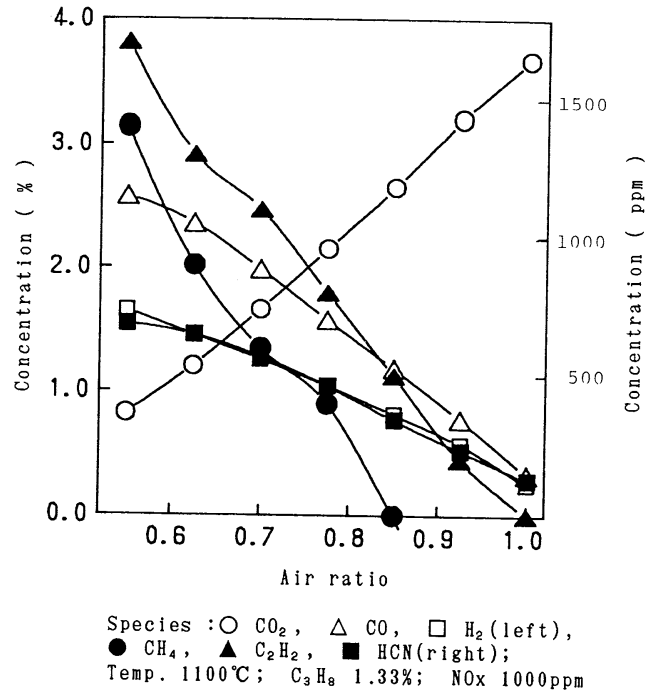

Fig. 3 Analysis of the effluent gas from one-stage reaction

解によっても生成していると考えられる。

ガス流速を11.2から $22.5 \mathrm{~cm} / \mathrm{sec}(\mathrm{STP})$ まで変化さ せたが，いずれの炭化水素についても $\mathrm{NO}_{\mathrm{x}}$ 転化率はほ とんど変化しなかったので，この範囲内では滞留時間 の影響は小さいと言える。

$\mathrm{NO}_{\mathrm{x}}$ との反応性が高いプロパンを還元剂として用い た場合の一段反応後のガス組成をFig. 3に示す。空気 比の低下とともに $\mathrm{CO}, \mathrm{H}_{2}$ 濃度が増大し, 少量ではあ るが $\mathrm{CH}_{4}, \mathrm{C}_{2} \mathrm{H}_{2}$ も生成する。 $\mathrm{N}_{2} \mathrm{O}$, 未反応の $\mathrm{C}_{3} \mathrm{H}_{8}$ は認め られなかった。炭化水素と $\mathrm{NO}_{\mathrm{x}}$ を酸素不足の条件下で 反応させたときに生成するHCNは, 空気比が低くな るほど濃度が高くなり，低空気比領域では転化したN $\mathrm{O}_{\mathrm{x}}$ の大部分が $\mathrm{HCN}$ になってい。Myerson ${ }^{2)}$, Yamazakiら ${ }^{8)}$ の実験結果よりも高い $\mathrm{HCN}$ への転化率 であった。一方, 高空気比領域では $\mathrm{NO}_{\mathrm{x}}$ の $\mathrm{HCN}$ への 転化率は低い。これは, 空気比の高い領域では生成し た $\mathrm{HCN} か ゙ さ ら に C N$ 等を経て $\mathrm{N}, \mathrm{NH}, \mathrm{NH}_{2}$ へ転化する 反応が起こりやすいためと考えられる。 $\mathrm{NH}_{3}$ の生成濃 度は低く, HCNの $5 \%$ 程度であった。これらの傾向 はプロパン以外の炭化水素についても同様であった。

一段反応後のガス中の未燃分を酸化するために二次 酸素の添加, 二次加熱を行った場合を二段反応と呼び, これによってCOやHCN等が完全に酸化されたときの， $\mathrm{NO}_{\mathrm{x}}$ の流入量に対する $\mathrm{NO}_{\mathrm{x}}$ の減少割合を $\mathrm{NO}_{\mathrm{x}}$ 除去率 (percent of $\mathrm{NO}_{\mathrm{x}}$ reduction) と表示する。未燃分の酸 化には酸素濃度, 二次加熱温度, ガス流速が大きな影

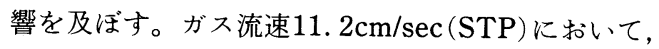

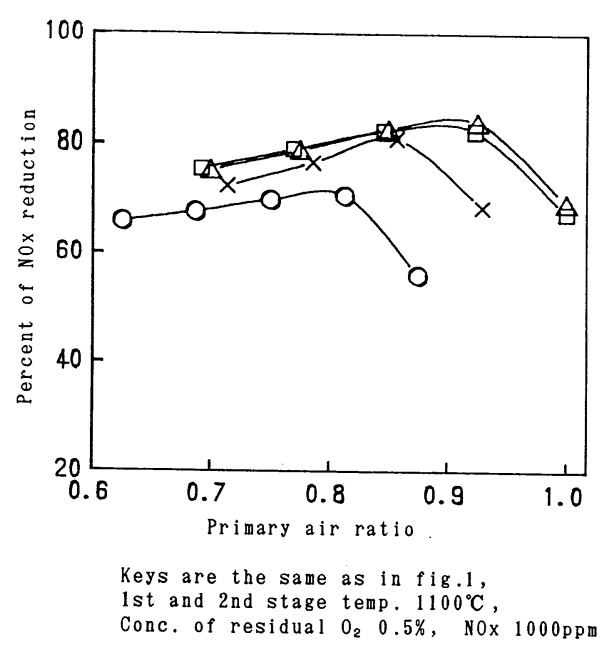

Fig. 4 Nitric oxides reduction in two-stage reaction

二段反応後の残存酸素濃度 $0.5 \%$ 以上, 二次加熱温度 $1100{ }^{\circ} \mathrm{C}$ 以上にすれば $\mathrm{CO}, \mathrm{HCN}, \mathrm{NH}_{3}$ は検出下限 (それ ぞれ $10 \mathrm{ppm}, 0.02 \mathrm{ppm}, 1 \mathrm{ppm}$ ) 以下の濃度にできるこ とがわかった。各炭化水素について，二段反応させた 場合の $\mathrm{NO}_{\mathrm{x}}$ 除去率をFig. 4に示す。どの炭化水素につ いても $\mathrm{NO}_{\mathrm{x}}$ 除去率は, 一次空気比の低い領域で, 一段 反応の場合の $\mathrm{NO}_{\mathrm{x}}$ 転化率より 10～20\%低下している。 これは，HCNの転化反応を経て (5)〜 (8) のNO再生反 応が起こるためと思われる。HCN転化反応によって 生成する $\mathrm{NH}_{2}, \mathrm{NH}, \mathrm{N}$ 等の化学種は (9) 〜 (13) の $\mathrm{N}_{2}$ 生成 反応にも関与しているので, HCNの全量がNOに戻る わけでなく，一部は $\mathrm{N}_{2}$ として固定されると考えられ る。一次空気比が低い汪どNO $\mathrm{NO}_{\mathrm{x}}$ 去率の低下度が大き いのは, 残存酸素濃度を一定にする場合, 一次空気比 が低いほど二次酸素添加量が多くなり, 反応中の $\mathrm{O}_{2}$, $\mathrm{OH}, \mathrm{O}$ 濃度が高くなって (5)〜 (8) のNO再生反応が活 発になるためであろら。含窒素化合物からNOが再生 する反応に対して酸素濃度の影響が大きいということ は高橋 3 )らも指摘している。また, HCNの酸素酸化 反応において $\mathrm{CO} や \mathrm{C}_{2} \mathrm{H}_{2}$ がNOの生成を促進するとい う報告 9 ) もあるので, 一次空気比の低い領域で濃度が 高いCO, $\mathrm{C}_{2} \mathrm{H}_{2}$ が (5) 〜 (8) のNO再生反応を促進してい る可能性もある。一方, 一次空気比の高い領域ではN $\mathrm{O}_{\mathrm{x}}$ 除去率がNO $\mathrm{N}_{\mathrm{x}}$ 転化率より高くなっている。一次空気 比が高い場合, 二次酸素添加量が少なく, 二段目の $\mathrm{O}_{2}, \mathrm{OH}, \mathrm{O}$ 濃度が低くなるので，上記とは逆に(5)〜 (8) のNO再生反応は抑制されるであろら。さらに，一次 空気比が高い領域では一段目の反応後の残存 $\mathrm{NO}_{\mathrm{x}}$ 濃度 
が高いので，(9)〜(11)の $\mathrm{N}_{2}$ 生成反応が促進される。(9) 〜(11)の反応が起こると $\mathrm{N}, \mathrm{NH}, \mathrm{NH}_{2}$ が $\mathrm{N}_{2}$ として固定さ れるばかりでなく，新たにNOを消隇させて $\mathrm{NO}_{\mathrm{x}}$ 除去 率を高める。一次空気比の高い領域では(9)〜(11)の $\mathrm{N}_{2}$ 生成反応が(5) (8)のNO再生反応および (12), (13) の $\mathrm{N}_{2}$ 生 成反応より優勢なために， $\mathrm{NO}_{\mathrm{x}}$ 除去が $\mathrm{NO}_{\mathrm{x}}$ 転化率より 高くなったものと考光られる。一次空気比の低い領域 でNO $\mathrm{N}_{\mathrm{x}}$ 去率が低くなり, 一次空気比の高い領域でN $\mathrm{O}_{\mathrm{x}}$ 除去率が高くなったため, $\mathrm{NO}_{\mathrm{x}}$ 除去率の最大値を与 える一次空気比の值は $\mathrm{NO}_{\mathrm{x}}$ 転化率の場合より高空気比 側に移動している。一方, 二次酸素添加量を増して残 存酸素濃度を高くしていった場合, $\mathrm{NO}_{\mathrm{x}}$ 除去率は一次 空気比の全領域に渡って少しずつ低下 (たとえば残存 酸素濃度が $0.5 \%$ から $1.0 \%$ になると $\mathrm{NO}_{\mathrm{x}}$ 除去率は 1 2 \%低下)した。これも, 酸素濃度が高くなって, $\mathrm{HCN}$ からのNO再生反応が促進されるためと考えられる。 また，ガス流速を 11.2 から $22.5 \mathrm{~cm} / \mathrm{sec}(\mathrm{STP})$ にした 場合, 一次空気比の高い領域で $\mathrm{NO}_{\mathrm{x}}$ 除去率が $5 \sim 10 \%$ 低下した。

還元剂としてプロパンを用いた場合の，一段反応， 二段反応に対する一次加熱温度の影響をFig. 5 , 6に示 す。一段反応では一次加熱温度が高くなるほどNO 転 化率が上昇するが，二段反応では一次加熱温度による $\mathrm{NO}_{\mathrm{x}}$ 除去率の変化は小さい。一次加熱温度が高く $\mathrm{NO}_{\mathrm{x}}$ 転化率が高いほど一段反応後の残存 $\mathrm{NO}_{\mathrm{x}}$ 濃度が低くな るため，(9)〜(11)の $\mathrm{N}_{2}$ 生成反応は起こりにくくなり， (5) （8)のNO再生反応や (12), (13) の $\mathrm{N}_{2}$ 生成反応が相 対的に優勢になると考えられる。その結果, 一次加熱 温度が高いほどNO $\mathrm{N}_{\mathrm{x}}$ 余去率の低下が大きくなり, 一

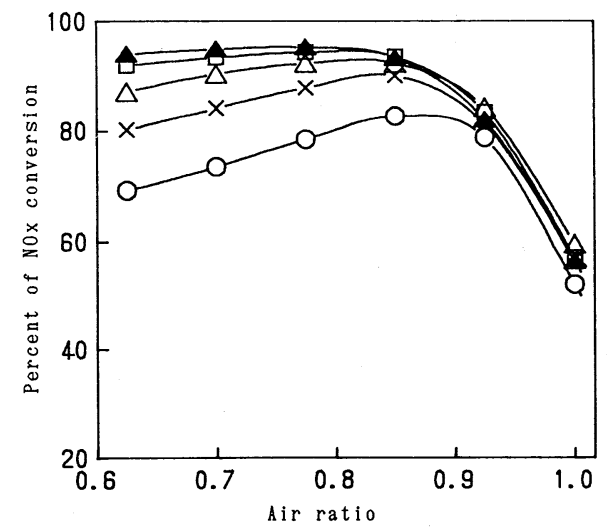

1st stage temp. : $\bigcirc 900, \times 950, \triangle 1000$, $\square 1050, \Delta 1100{ }^{\circ} \mathrm{C} ; \mathrm{C}_{3} \mathrm{H}_{8} 1.33 \%$;

NOX $1000 \mathrm{ppm}$

Fig. 5 Effect of temperature on one-stage reaction

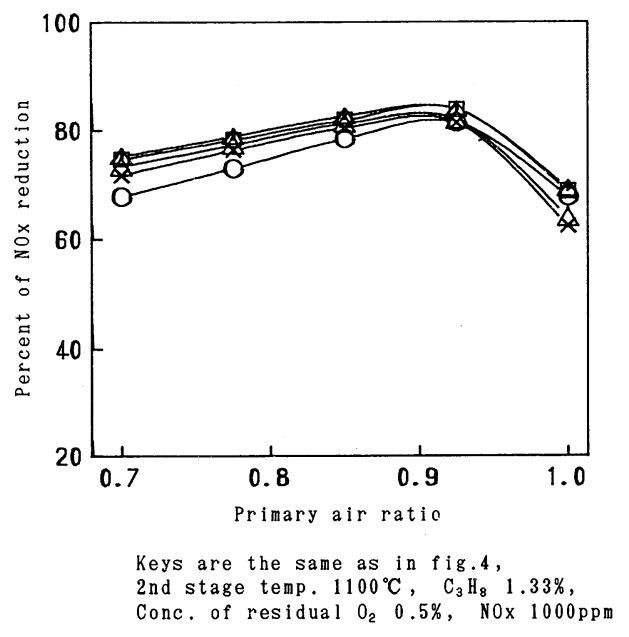

Fig. 6 Effect of 1 st stage temperature on two-stage reaction

次加熱温度の違いによって生じた $\mathrm{NO}_{\mathrm{x}}$ 転化率の大きな 差が，二段反応後のNOx除去率では小さくなっている ものと思われる。二段反応における一次加熱温度の影 響は上記のように小さいが，炭化水素の種類によって

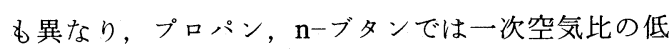
い領域, メタンでは一次空気比の高い領域, エタンで は全領域で比較的大きかった。一次加熱温度, 一次空 気比, 炭化水素の種類によって, 一段反応後の残存酸 素濃度, $\mathrm{HCN}$ を始めとする中間生成物の濃度が異な るために，二段反応を行ったときの $\mathrm{N}_{2}$ 生成反応と $\mathrm{NO}$ 再生反応のバランスも影響を受け，上記のような複雑 な結果になるものと思われる。

二段反応における $\mathrm{NO}_{\mathrm{x}}$ 除去率に対する $\mathrm{CO}_{2}, \mathrm{SO}_{2}, \mathrm{H}_{2}$ Oの影響をFig. 7に示す。試料ガス中に $\mathrm{CO}_{2}$ を $10 \%$ 添 加しておくと， $\mathrm{CO}_{2}$ を添加していない場合と比較して， 一次空気比の高い領域でNO $\mathrm{NP}_{\mathrm{x}}$ 去率が $10 \%$ 程度低下す るが, 一次空気比の低い領域では $\mathrm{CO}_{2}$ の影響はほとん ぞ無い。また, $\mathrm{SO}_{2} 500 \mathrm{ppm}, \mathrm{H}_{2} \mathrm{O} \quad 10 \%$ をれぞれ添 加した場合の $\mathrm{NO}_{\mathrm{x}}$ 除去率への影響は一次空気比にかか わらず小さかった。一段反応においては, 空気比の高 い領域で $\mathrm{CO}_{2}$ の添加によって $\mathrm{NO}_{\mathrm{x}}$ 転化率が約 $6 \%$ 低下 したが, 空気比の低い領域では添加物の影響は汪とん ど見られなかった。これらの傾向はプロパン以外の炭 化水素についてもほ湆同様であった。 $\mathrm{CO}_{2}$ を添加して 一段反応させた後のガス中のHCNを測定したところ， 空気比の高い領域において, メタン, エタンで50〜70 \%, プロパン, $\mathrm{n}$ ーブタンで30〜40\%, $\mathrm{CO}_{2}$ を添加して いない場合より濃度が低下していることがわかった。 


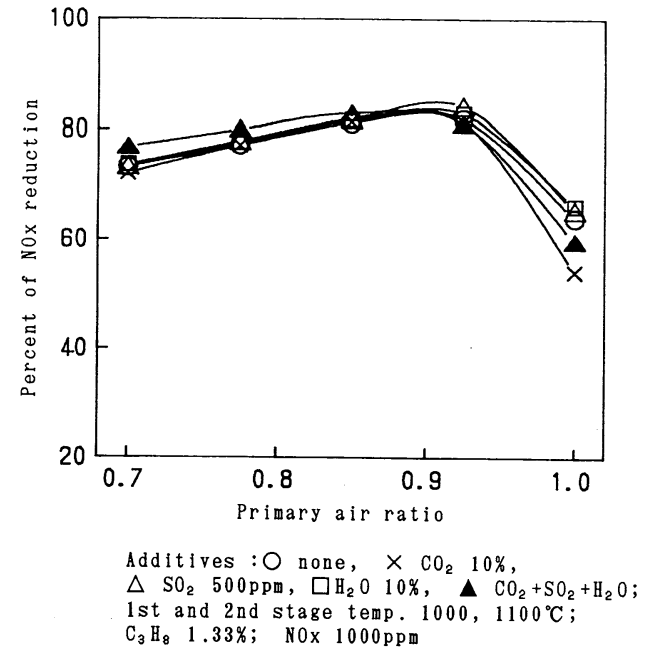

Fig. 7 Effect of additives on two-stage reaction

この低下率は空気比が低くなるにつれて小さくなった。 $\mathrm{CO}_{2}$ を添加したことによる $\mathrm{NO}_{\mathrm{x}}$ 転化率の低下度より $\mathrm{HCN}$ 濃度の低下度の方が大きいことから $\mathrm{CO}_{2}$ は $\mathrm{HCN}$ の分解反応を促進していると考元られる。Haynes $ら^{10)}$ とよれば， $\mathrm{CO}_{2}$ は $\mathrm{CN}+\mathrm{CO}_{2} \rightarrow \mathrm{OCN}+\mathrm{CO}$ なる応 を通じてHCNの分解に寄与するといら。燃料過㮃条 件下で $\mathrm{CO}_{2}$ がHCNの分解を促進することはYamazaki $5^{8)}$ も報告している。彼らは同時に, $\mathrm{CO}_{2}$ にってNO 濃度の低下が促進されることも認めており，この点は 本研究の結果とは異なる。この原因に関しては今のと ころ不明である。 $\mathrm{CO}_{2}$ の添加によって二段反応後の $\mathrm{N}$ $\mathrm{O}_{\mathrm{x}}$ 除去率が一次空気比の高い領域で低下するのは, C $\mathrm{O}_{2}$ が一段めの反応でHCN濃度を低下させるので，二 段めでHCNから， N, NH, $\mathrm{NH}_{2}$ の生成が阻害されて, $\mathrm{NO}$ との $\mathrm{N}_{2}$ 生成反応が起こりにくくなるためと考えら れる。

$\mathrm{NO}_{\mathrm{x}}$ 初濃度 $1000 \mathrm{ppm}$ と250ppmについて, プロパン 濃度を変えて一段反応を行った結果をFig. 8に示す。 プロパン濃度を低くしていくと, 空気比 1.0 のころ を除き， $\mathrm{NO}_{\mathrm{x}}$ 転化率は低くなるが，この傾向はNO 濃度が高い場合にとくに著しい。一方，同じプロパン 濃度のところで比較すると, プロパン濃度が高い場合 にはNO $\mathrm{x}_{\mathrm{x}}$ 初濃度が高い方が $\mathrm{NO}_{\mathrm{x}}$ 転化率が高く, プロパ ン濃度が低い場合には逆に $\mathrm{NO}_{\mathrm{x}}$ 初濃度が低い方が $\mathrm{NO}_{\mathrm{x}}$ 転化率が高くなっている。

$\mathrm{NO}_{\mathrm{x}}$ 初濃度 $1000 \mathrm{ppm}$ と250ppmについて，プロパン 濃度を変えて二段反応を行った結果をFig. 9に示す。 二次酸素は, 二段反応後の残存酸素濃度が $0.5 \%$ になる
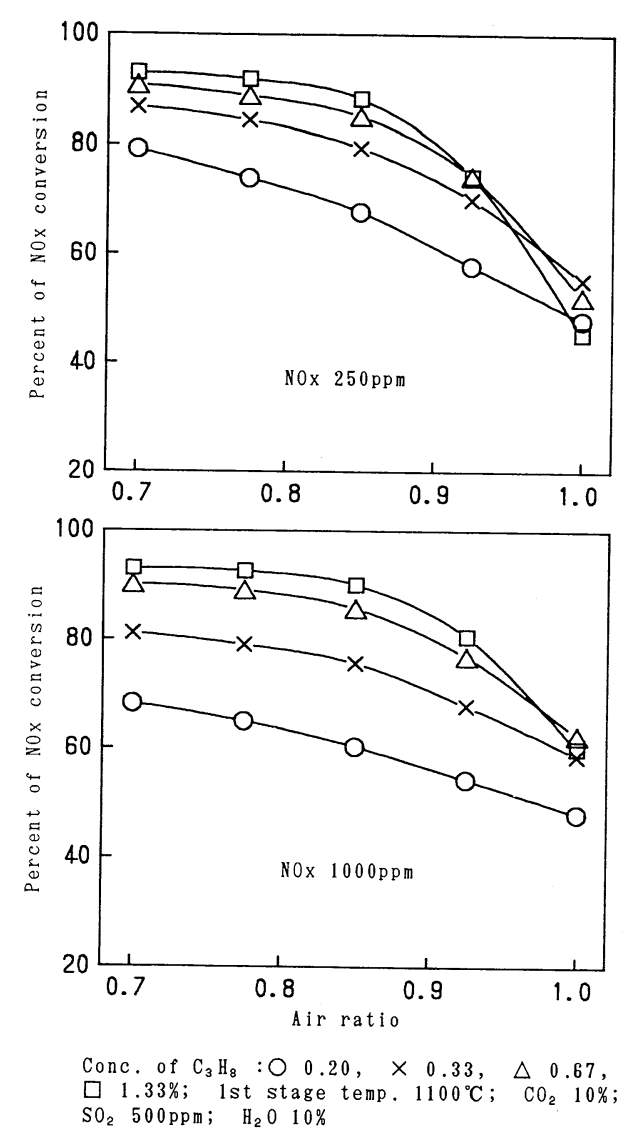

Fig. 8 Effect of propane concentration on one-stage reaction

ように添加した。一段反応時の $\mathrm{NO}_{\mathrm{x}}$ 転化率がプロパン 濃度の増加とともに高くなったのに対して, 二段反応 時の $\mathrm{NO}_{\mathrm{x}}$ 除去率は単調には高くならず，プロパン濃度 $0.33 \sim 0.67 \%$ のころで最高値を示した。同様にnブタンでは $0.25 \sim 0.5 \%$ のころでNO $\mathrm{N}_{\mathrm{x}}$ 除去率が最高 になったが, メタン, エタンでは濃度が増加するほど $\mathrm{NO}_{\mathrm{x}}$ 除去率は高くなった。プロパン濃度を高くしてい くと, $\mathrm{NO}_{\mathrm{x}}$ 除去率は $\mathrm{NO}_{\mathrm{x}}$ 転化率より大幅低下寸るよ らになる。この傾向は $\mathrm{NO}_{\mathrm{x}}$ 初濃度が低い場合にとくに 著しい。プロパン濃度が高い場合に $\mathrm{NO}_{\mathrm{x}}$ 除去率の低下 が大きいのは，プロパン濃度が高いと二次酸素添加量 が多いので二段目の反応時の酸素濃度が高くなって(5) 〜 (8)のNO再生反応が促進されるためと考觉られる。 また， $\mathrm{NO}_{\mathrm{x}}$ 初濃度が低くなると二段反応後の $\mathrm{NO}_{\mathrm{x}}$ 除去 率が低下するが，この傾向はプロパン濃度が高い場合 にとくに著しい。酸素が過剩に存在して $\mathrm{O}_{2}, \mathrm{O}, \mathrm{OH}$ の 濃度が一定とみなせる場合, NO再生速度は(5) 

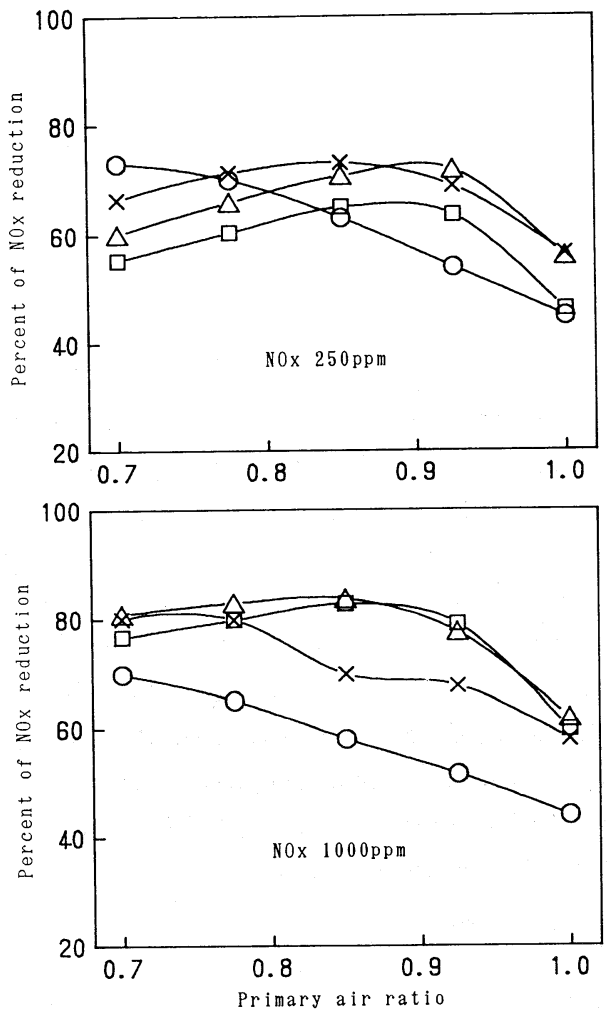

Keys are the same as in fig. $7 ; 1$ st and 2 nd stage temp. $1100^{\circ} \mathrm{C} ; \mathrm{CO}_{2} 10 \% ; \quad \mathrm{SO}_{2} 500 \mathrm{ppm}$; $\mathrm{H}_{2} \mathrm{O} 10 \%$; Conc. of residual $\mathrm{O}_{2} 0.5 \%$

Fig. 9 Effect of propane concentration on two-stage reaction

〜 (8)式から $\mathrm{N}$ たはNH濃度に関して一次と考えられ る。一方, $\mathrm{N}_{2}$ の生成速度は (9) (13) 式から $\mathrm{N}, \mathrm{NH}, \mathrm{N}$ $\mathrm{H}_{2}$, NOの中の二分子の濃度に関してそれぞれ一次と 思われる。 $\mathrm{N}, \mathrm{NH}, \mathrm{NH}_{2}$ は(1)〜 (4) の NO転化反応抢よ びHCNの転化反応を経て生成するのだから, 結局, $\mathrm{NO}$ 再生速度, $\mathrm{N}_{2}$ 生成速度はNO初濃度に関して, そ れぞれ一次，二次の依存性を持つと考兄られる。それ 故, $\mathrm{NO}_{\mathrm{x}}$ 初濃度を低くすると, (9) (13) の $\mathrm{N}_{2}$ 生成反応 の寄与は $(5) \sim(8)$ のO再生反応の寄与よりも急激に 小さくなると思われる。これが，二段反応においてN $\mathrm{O}_{\mathrm{x}}$ 初濃度を低くしたときのNO 除去率が著しく低下す る理由であろら。

\section{4. 結 論}

$\mathrm{NO}_{\mathrm{x}}$ をプロパン等の炭化水素と反応させた場合, $\mathrm{N}$ $\mathrm{O}_{\mathrm{x}}$ の転化反応は空気比 1.0 以下の還元雾囲気下で活発 に進み (一段反応), 空気比が低い:ど $\mathrm{NO}_{\mathrm{x}}$ から $\mathrm{HCN}$ へ の転化率が高くなった。中間生成物を酸化するために
二次酸素の添加，二次加熱 (二段反応) が必要で，ガス 流速 $11.2 \mathrm{~cm} / \mathrm{sec}(\mathrm{STP})$ において, 二次加熱温度 $1100{ }^{\circ} \mathrm{C}$ 以上, 残存酸素濃度 $0.5 \%$ 以上にすれば完全酸 化できることがわかった。 HCNの酸化時に，HCNの 転化生成物からNOが再生する反応と $\mathrm{N}_{2}$ が生成する反 応の両方が考兄られるが，酸素濃度が高く， $\mathrm{NO}_{\mathrm{x}}$ 濃度 が低い場合には前者の寄与が大きくなり，二段反応時 の $\mathrm{NO}_{\mathrm{x}}$ 除去率は低下する。メタン，エタンよりもプロ パン, $\mathrm{n}$-ブタンの方が高い $\mathrm{NO}_{\mathrm{x}}$ 転化率, $\mathrm{NO}_{\mathrm{x}}$ 除去率を 示すとともに, 一次空気比の高い領域でも高い $\mathrm{NO}_{\mathrm{x}}$ 転 化率， $\mathrm{NO}_{\mathrm{x}}$ 除去率が得られた。一次加熱温度を900$1100{ }^{\circ} \mathrm{C}$ の範囲で変えたところ, 一段反応時の $\mathrm{NO}_{\mathrm{x}}$ 転化 率は温度が高いほど高くなったが，二段反応時の $\mathrm{NO}_{\mathrm{x}}$ 除去率は一次加熱温度による変化が小さかった。炭化 水素濃度を高くしていくと $\mathrm{NO}_{\mathrm{x}}$ 転化率は高くなるが, $\mathrm{NO}_{\mathrm{x}}$ 除去率はプロパン濃度 $0.33 \sim 0.67 \%, \mathrm{n}$-ブタン濃 度 $0.25 \sim 0.5 \%$ で最大值を示す。ガス流速を大きくし ても $\mathrm{NO}_{\mathrm{X}}$ 転化率の変化は小さかったが， $\mathrm{NO}_{\mathrm{x}}$ 除去率は 一次空気比の高い領域で低下した。 $\mathrm{CO}_{2}$ は一次空気比 の高い領域でHCNの分解反応を促進し, $\mathrm{NO}_{\mathrm{x}}$ 転化率, $\mathrm{NO}_{\mathrm{x}}$ 除去率を低下させたが, $\mathrm{SO}_{2}, \mathrm{H}_{2} \mathrm{O}$ の影響は小さか った。

\section{文献}

1) Wendt, J. O. L., Sternling, C. V. and Matovich, M. A., 14th Symposium(International) on Combustion, p. 897 (1973)

2) Myerson, A. L., 15th Symposium (International) on Combustion, p. 1085 (1975)

3）高橋恭郎, 坂井正康, 村上信明, 仙石忠正, 国本 武志, 羽田壽夫, 平山昭, 金子祥三, 三菱重工技 報，17，923(1980)

4）高橋恭郎, 坂井正康, 河村友桘, 国本武志, 羽田 壽夫，村石顕介，金子祥三，ibid., 17, 929 (1980)

5）宮寺達雄, 公害, 22, 95 (1987)

6）宮寺達雄, 公害, 22, 341 (1987)

7) Song, Y. H., Blair, D. W., Siminski, V. J. and Bartok, W., 18th Symposium (International) on Combustion, p. 53 (1981)

8) Yamazaki, S., Hiratsuka, M. and Fujitani, Y., Combustion Science and Technology, 20, 25(1979)

9) Houser, T. J., McCarville, M. E. and Houser, B. D., ibid., 29,101 (1982)

10) Haynes, B. S., Iverach, D. and Kirov, N. Y., 15th Symposium (International) on Combustion, p.1103 (1975) 


\title{
Reduction of Nitric Oxides by Hydrocarbon
}

\author{
Tatsuo MIYADERA
}

(National Research Institute for Pollution and Resources)

SYNOPSIS:- The reaction of nitric oxides with methane, ethane, propane and $n$-butane was investigated in the heating temperature range $900-1100^{\circ} \mathrm{C}$ using a tubular flow reactor.

In one-stage reaction, the conversion of $\mathrm{NO}_{\mathrm{x}}$ was accelerated at air ratio below 1.0 and the percent of conversion of $\mathrm{NO}_{\mathrm{x}}$ to $\mathrm{HCN}$ increased with the decrease of air ratio. The intermediate products were oxidized by adding secondary oxygen and by reheating. They were oxidized completely at reheating temperature above $1100^{\circ} \mathrm{C}$ and at residual oxygen concentration above $0.5 \%$. It was suggested that both $\mathrm{NO}$ regeneration and $\mathrm{N}_{2}$ production were taking place on oxidation of $\mathrm{HCN}$. The ratio of $\mathrm{NO}$ regeneration increased at higher oxygen and lower $\mathrm{NO}_{\mathrm{x}}$ concentration, and the percent of $\mathrm{NO}_{\mathrm{x}}$ reduction in two-stage reaction decreased. Propane and $\mathrm{n}$-butane showed higher percent of $\mathrm{NO}_{\mathrm{x}}$ conversion and reduction than methane and ethane at high primary air ratio. The percent of $\mathrm{NO}_{\mathrm{x}}$ conversion increased with the increase of concentration of hydrocarbon. The maximum percent of $\mathrm{NO}_{\mathrm{x}}$ reduction was obtained at concentrations of propane $0.33 \sim 0.67 \%$ or $n$-butane $0.25 \sim 0.5 \%$. The effect of first-stage temperature, gas flow rate, $\mathrm{CO}_{2}, \mathrm{SO}_{2}$ and $\mathrm{H}_{2} \mathrm{O}$ was also investigated.

\section{Key Words}

Nitric oxides, Reduction, Hydrocarbon, Flow reactor 